\title{
The Effect of Margin Income and Shares of Results on Net Profit Achieved In BRI Syariah
}

\section{Astri Anantasari Azizah1, Ade Yusuf Mujaddid², Dessy Noor Farida ${ }^{3}$}

1,2,3 Walisongo State Islamic University, Semarang, Indonesia. astrianantasari.a@gmail.com

\begin{abstract}
Purpose - This study aims to analyze the effect of murabahah margin income, istishna 'margin income, mudharabah profit sharing, and musyarakah revenue sharing on net profit atBRI Syariah Bankduring 20142019.

Method - The research approach used in this research is a quantitative approach. In determining the sample, the research was carried out by using purposive sampling method. In this study, data was collected from secondary data, through quarterly financial reports published by Bank BRI Syariah in 2014-2019. The data analysis technique used is multiple linear regression data analysis techniques, Where researchers can conduct research between two or more independent variables on the dependent variable.
\end{abstract}

Result - The results show that murabahah margin income has a negative and insignificant effect on net profit, istishna 'margin income has a negative and insignificant effect on net income, the profit sharing income from mudharabah has a positive and significant effect on net profit, and the profit sharing income for musyarakah has a negative and negative effect. not significant to net income during 2014-2019.

Implication - This study uses BRI Syariah Financial Report data.

Originality - This study looks at the relationship between the variable margin income and profit sharing income on the net profit variable generated by Bank BRI Syariah.

Keywords: Murabahah Margin Income, Istishna 'Margin Income, Mudharabah Revenue Sharing, Musharaka Revenue Sharing, and Net Profit. 


\section{Introduction}

Financial Institutions or what can be called Financial Institutions are institutions whose activities are all related to financial services. The activities are in the form of collecting and distributing funds. Fundraising is an activity to collect funds belonging to the people who have excess funds, so that these funds are collected in financial institutions. Distribution of funds is an activity carried out at financial institutions aimed at the welfare of the people at large, namely in the form of channeling funds to the public or companies in need of funds, this activity is commonly referred to as investment in companies or other service activities that can improve the standard of living of the people at large.

In a Financial Institution system, there are two types that must be understood, the first is Bank-oriented Financial Institutions, activities carried out in the form of collecting and channeling funds, collecting funds from public funds that have excess funds then depositing them with the Bank, second namely distribution activities whose activities provide a portion of the funds to people who are in need. For the second type, namely Non-Bank Financial Institutions, different from the previous definition, in this financial institution the activity of collecting funds is by issuing securities and channeling it in the form of funding for companies (Mardani, 2015).

The purpose of the bank is not only to lend funds (credit) to customers who are in need, another goal is to be able to move funds, exchange funds, and become a place to pay for everything, such as: tuition payments, electricity payments, water payments, telephone payments, payments taxes, and other payments. The definition of a Bank is a business entity whose goal is to collect funds and channel it back in order to improve people's lives for the better. Various sectors need to require banks as partners in growing their business. Such as in the trade sector, industrial sector, culinary sector, plantation sector, and other sectors (Muchtar, 2016). If these sectors develop well,

In 1991 Sharia Bank began to exist in Indonesia. In carrying out existing activities at Sharia Banks and Conventional Banks, there is actually a similarity, 
namely the activities of collecting funds from customers or the public, and also being able to channel funds to customers in the form of loans, the only thing that distinguishes between Islamic Banks and Conventional Banks is in doing All types of activities of a Sharia Bank are based on "sharia principles" so that they do not carry out activities based on the principles of usury, maisir, gharar, haram, and zalim. So, if you want to raise funds or make loans to Islamic banks, we still adhere to sharia principles as the main foundation of Islam. The operational mechanism that is carried out in Islamic Banks uses Islamic principles, therefore it will not cause harm to one party, while the other party will benefit. However, in conventional banks the operational mechanism uses an interest system which is still forbidden in Islamic teachings (Lasmana, 2009).

On November 17, 2008, it was recorded that BRI Bank had started operating, since the beginning of its operation it had carried out all kinds of activities within its mechanism, always applying or having principles on Islamic teachings, namely the Al-Qur'an and Sunnah. BRI Syariah has a variety of products that are provided to customers or prospective customers. So that these customers can choose according to their desired needs. BRI Syariah also implements contracts on various products. Products with the buying and selling principle are known to use the murabahah and istishna contracts. Both contracts have the principle of sale and purchase in which the bank, as the seller, is to finance all or part of the price of the goods that has been mutually agreed upon with the customer or buyer. The difference between the two contracts is that if the murabahah contract of the bank acts as a seller and before carrying out transaction activities, the bank must provide information about the selling price and purchase price to the customer, while istishna 'is a sale and purchase by ordering goods where the Bank is the seller. The existing contract at BRI Syariah Bank uses the profit sharing principle, namely mudharabah and musyarakah. Both contracts have the principle of cooperation between the bank and the customer to carry out a project. The difference between the two lies in, if the mudharabah contract of the bank fully provides funds for the project to be worked on, but in the musyarakah contract, 
the bank and the customer both invest their capital to build a joint project. The bank must provide information about the selling price and purchase price to the customer, while istishna 'is a sale and purchase by ordering goods where the Bank is the seller. The existing contract at BRI Syariah Bank uses the profit sharing principle, namely mudharabah and musyarakah. Both contracts have the principle of cooperation between the bank and the customer to carry out a project. The difference between the two lies in, if the mudharabah agreement, the bank fully provides funds for the project to be worked on, but in the musyarakah contract, the bank and the customer both invest their capital to build a joint project. The bank must provide information about the selling price and purchase price to the customer, while istishna 'is a sale and purchase by ordering goods where the Bank is the seller. The existing contract at BRI Syariah Bank uses the profit sharing principle, namely mudharabah and musyarakah. Both contracts have the principle of cooperation between the bank and the customer to carry out a project. The difference between the two lies in, if the mudharabah contract of the bank fully provides funds for the project to be worked on, but in the musyarakah contract, the bank and the customer both invest their capital to build a joint project. Both contracts have the principle of cooperation between the bank and the customer to carry out a project. The difference between the two lies in, if the mudharabah contract of the bank fully provides funds for the project to be worked on, but in the musyarakah contract, the bank and the customer both invest their capital to build a joint project. Both contracts have the principle of cooperation between the bank and the customer to carry out a project. The difference between the two lies in, if the mudharabah agreement, the bank fully provides funds for the project to be worked on, but in the musyarakah contract, the bank and the customer both invest their capital to build a joint project.

If the financing channeled by the bank to the customer runs smoothly, in the sense that the customer can return the loan to the bank on time, it will affect the income that a bank will generate. However, if the financing activity is not smooth, it will affect the bank's income which will decrease. Income in a bank 
The Effect of Margin Income and Shares of Financing ...

is the most important thing for a bank. If the income always increases, it shows that the bank has a great opportunity to increase its business (Mashilal, 2020).

Net income is the income obtained from a company, after deducting the selling price or operating activities and expenses that must be paid. Net income can be a reference in determining the success of a company. Basically, the business activities carried out by the Bank are directed to achieve maximum net profit, because net income is a measure used to evaluate whether the bank has received adequate compensation from the activities of channeling funds.

Therefore the purpose of this paper is (1) To determine the effect of murabahah margin income on the net profit generated by BRI Syariah, (2) To determine the effect of istishna 'margin income on the net profit generated by BRI Syariah,(3) To determine the effect of mudharabah profit sharing on the net profit generated by BRI Syariah, (4) To determine the effect of Musyarakah revenue sharing on the net profit generated by BRI Syariah, (5) And to determine the effect of margin income and revenue sharing simultaneously to the net profit generated by BRI Syariah.

\section{Literature Review}

\section{Islamic Bank}

Sharia Bank is a financial institution that in carrying out its activities is based on sharia principles. As stipulated in the Sharia Banking Law, Sharia banking activities are not allowed to conflict with the principles of syariah. Sharia banking activities, namely collecting funds owned by the community and providing financing to people in need with the principle of profit sharing. These activities are not allowed to use principles that contain elements of usury, maisir, gharar, haram, and zalim. Because these elements are against the principles of sharia (Cahya Rosyadah et al., 2020).

In a Sharia Bank there is an institutional aspect consisting of a Sharia Commercial Bank (BUS) and a Sharia Rural Bank (BPRS), while in the legal aspect of a sharia bank it is called a Limited Liability Company (PT). 
The similarities that exist in Islamic Commercial Banks (BUS) and Sharia Rural Banks (BPRS) with conventional banks and Islamic banks can be seen in terms of their business activities, which include: 1) In the field of collecting public funds in the form of savings / investment (liability product); 2) In the field of distribution of funds to the public in the form of credit or company investment (product assets); 3) Provision of bank services (service product).

Therefore, in terms of business, the two banks have no differences. The difference is seen when carrying out the business. For conventional banks, the way to get their income is by means of the interest system. In contrast to Islamic banking, in conducting its business, it does not use an interest system or what is commonly called usury, but instead uses a profit and loss sharing system that is agreed between the two parties that are cooperating (A. Wangsawidjaja, 2012).

\section{Sources of Islamic Bank Income}

Results of distribution of funds provided to customers can provide income for Islamic banks. The distribution of these funds can be in the form of: 1) Mudharabah contracts and musyarakah contracts which are commonly referred to as profit sharing; 2) The sale and purchase contract (al-Bai ') which can use the murabahah contract, the istishna' contract, and the salam contract. In the sale and purchase contract the income is called profit margin; 3) Ijarah and ijarah wa iqtina contracts which are commonly referred to as rental income; 4) Other banking services, obtained from administration fees or fees obtained at a bank (Andriyanto Et all, 2019).

\section{Profit Margin Concept}

In determining the profit margin, Islamic Banks rely on financing that is distributed to their customers. If the financing is carried out smoothly, the profit / margin will be high. However, if the distribution of funds provided by customers does not go well, there will be losses to the Bank. These are financing such as mudharabah financing, murabahah financing, musyarakah financing, istishna 'financing, salam financing, and ijarah financing. 
The Effect of Margin Income and Shares of Financing ...

In carrying out a financing from a bank to its customer, if the customer is able to make a refund of the financing to the bank in a timely manner, without any congestion funds, the Bank will receive income in the form of profits generated from the distribution of these funds.

In making financing, customers usually pay funds to the Bank as a result of a sale and purchase transaction or lease, the payment is made in installments within a predetermined time between the two parties. The amount of the financing value provided by the bank to the customer is the customer's obligation to pay it off or it can be said with debt. The debt must be paid in accordance with the agreement of the two parties (Aufa et al., 2019).

Transactions using a murabahah contract are a sale and purchase agreement with two parties between the seller and the buyer on the condition that the seller informs the buyer of the cost of the beaver or the object to be sold. So that the buyer knows transparently what the cost of goods and the profit margin will be given to the seller. In this murabahah contract, customers can also pay for goods or objects purchased in cash or installments (Sudarsono, 2003).

Transactions using istishna 'contracts are transactions of buying and selling goods by placing orders from sellers to produce goods according to their wishes in accordance with sharia principles. An istishna 'transaction occurs when a company works or produces the goods ordered by the buyer. The goods that are the object of the order must have clear quality and specifications so that they do not experience errors during work. Manufactured goods become goods that are often ordered using the istishna 'contract. This can be in the form of food / beverage products, household products, automotive products, or other manufactured products. Payment can be made at the beginning of the order or in installments, according to the agreement between the two parties (Ascarya, 2007).

\section{Profit Sharing Concept}

Profit Sharing Principle Is a cooperation between two or more parties, with the aim of carrying out common interests in the business field by providing 
mutual capital. Profit sharing in the principle of profit sharing is obtained from the results of a jointly run business, as well as profit sharing based on a percentage of the results in accordance with the agreement between the parties running the business.

Investments for parties implementing the profit sharing principle are not required to have equal capital from one party to another, according to the capabilities of the parties. Profits in running a business can be divided according to the beginning of the agreement between the parties running. As well as for the losses can be the responsibility according to the percentage invested. This provision refers to the rule of fiqh "Profits (profits) are based on different stipulated requirements, while losses are based on the levels of both assets" " (Naja, 2011).

The definition of mudaraba according to the DSN fatwa No. 07 / DSNMUI / IV / 2000 are as follows: "Mudharabah is financing channeled by LKS to other parties for a productive business. In this financing, LKS as shahibul maal (owner of funds) finances $100 \%$ of the needs of a project (business), while the entrepreneur (customer) acts as a mudharib or business manager " (Usman, 2009).

Musyarakah agreement is a cooperation activity between two or more parties to conduct a business with the aim of making a profit, investment is carried out by both parties with different ratios, in the event of a loss it will be divided based on the proportion of the capital of each party (Huda \& Fajri, 2019).

\section{Profit}

Profit is the difference in acceleration that has been deducted from the operational costs of doing a business. Ordinary profit is calculated periodically once a year, the aim is to find out whether the company is in a profit / loss state. If there are signs of loss, the company can take action for the company so that it does not suffer losses (Age, 2005).

\section{Hypothesis}


The Effect of Margin Income and Shares of Financing ...

Based on the goals, objectives of the literature, and previous research, the following research hypotheses can be formulated in this study: H1. Murabahah margin income variable has a positive effect on net income; $\mathrm{H} 2$. The istishna margin income variable has a positive effect on net income; H3. The profit sharing variable of mudharabah has a positive effect on net income; H4. Musyarakah profit sharing variable has a positive effect on net income.

\section{Methods}

The writing method used in this study is a research method quantitative. Quantitative research is research that operates using numbers, as well as the existence of rules and logic in it. In quantitative research, the work process is carried out by finding problems that can be measured using numbers. The aim is to test the variables in the study and look for generalizations that have predictive value or can predict a symptom. This study aims to systematically describe margin income, revenue sharing, and net income obtained at BRI Syariah Bank for the period 2014-2019.

Juliana Putri and Intan Raudhatul Ma'wa (2017) show that mudharabah profit sharing and musyarakah profit sharing have a positive and significant effect on the net profit generated by Bank Syariah Mandiri for the 2013-2016 period.

Gatot Jalakaca Putra and Drs. Moh. Djazari, M.Pd. (2019) show that the mudharabah profit sharing results show negative and insignificant results on net income, but the musyarakah profit sharing and murabahah profit margin results show a positive and significant effect on net income at Bank BNI Syariah.

Eva Nuraisyah \& Herry Winarto (2019) show that the profit sharing income of mudharabah and musyarakah has a very strong influence on the net profit generated by BNI Syariah Bank for the period 2012-2018 because both show a positive relationship.

\section{Results and Discussion}

\section{Description Test}


Astri Anantasari Azizah, Ade Yusuf Mujaddid, Dessy Noor Farida

Table 2. Descriptive Data Test Results

\begin{tabular}{ccccc}
\hline & N & Minimum & Maximum & Mean \\
\hline Murabahah Margin Income & 24 & 340296 & 1666799 & 950562.42 \\
Istishna Margin Income ' & 24 & 87 & 3101 & 1061.50 \\
Mudharabah Revenue Sharing & 24 & 13750 & 167105 & 71834.04 \\
Musyarakah Revenue Sharing & 24 & 86081 & 900968 & 352609.83 \\
Net profit & 24 & 2384 & 170202 & 71932.63 \\
Valid N (listwise) & 24 & & &
\end{tabular}

The results of the descriptive data test in Table 2 show an $\mathrm{N}$ value of 24 data, taken through quarterly financial reports in 2014-2019. Murabahah margin income in units of millions of rupiah shows the lowest unit value (minimum) of 340296, the highest unit value (maximum) of 1666799 and the average sataun (mean) of 950562.42. Istishna 'margin income in millions of rupiah shows the lowest (minimum) unit value of 87 , the highest (maximum) value of 3101 and the average (mean) of 1061.50. Mudharabah profit sharing income in millions of rupiah shows the lowest (minimum) unit value of 13750, the highest (maximum) value of 167105 and the average (mean) of 352609.83 . Then the revenue sharing of musyarakah in units of millions of rupiah shows the lowest (minimum) unit value of 86081, the highest (maximum) value of 900968 and the average (mean) of 352609.83. And the result of net profit in units of millions of rupiah shows the lowest unit value (minimum) of 2384, the highest value (maximum) of 170202 and the average (mean) of 71932.63.

Normality testing using the One-Sample Kolmogorov-Smirnov Test or commonly known as the KS Test functions to test the normality of data through its residual value. Good data is normal data in its distribution. The basis for decision making in the normality test is: if the significance value is greater than $\alpha=0.05$, the data is normally distributed. On the other hand, if the significance value is less than $\alpha=0.05$ then the data is not normally distributed. Based on the test results, it is known that the residual significance value is $0.200>0.05$, which means that it has met the data normality requirements through the OneSample Kolmogorov-Smirnov Test or KS test. 
The Effect of Margin Income and Shares of Financing ..

Table 3. Normality Test Results

\begin{tabular}{ccc}
\hline & & Unstandardized Residual \\
\hline Normal Parametersa, $\mathbf{b}$ & Mean & $\mathbf{2 4}$ \\
& Std. Deviation & .0000000 \\
Most Extreme Differences & Absolute & 33026.02677 \\
& Positive & .128 \\
& Negative & .099 \\
& & -128 \\
Statistical Test & .128 \\
Asymp. Sig. (2-tailed) & & $.200 \mathrm{c.d}$ \\
\hline
\end{tabular}

a. Test distribution is Normal.

b. Calculated from data.

c. Lilliefors Significance Correction.

d. This is a lower bound of the true significance.

Normality testing using the One-Sample Kolmogorov-Smirnov Test or commonly known as the KS Test functions to test the normality of data through its residual value. Good data is normal data in its distribution. The basis for decision making in the normality test is: if the significance value is greater than $\alpha=0.05$, the data is normally distributed. On the other hand, if the significance value is less than $\alpha=0.05$ then the data is not normally distributed. Based on the test results, it is known that the residual significance value is $0.200>0.05$, which means that it has met the data normality requirements through the OneSample Kolmogorov-Smirnov Test or KS test.

Based on the test results This shows that Murabahah margin income gets a Tolerance value of 0.22 and VIF $4.513<10$ means that murabahah margin income does not have multicollinearity symptoms. Istishna 'margin income obtained a Tolerance value of 0.713 and VIF $1.403<10$, which means that istishna' margin income is not affected by multicollinearity symptoms. Mudharabah profit sharing income obtains a Tolerance value of 0.396 and VIF $2.528<10$, which means that the mudharabah profit sharing income does not have a symptom of multicollinearity. Musyarakah profit sharing income gets a Tolerance value of 0.348 and VIF $2.877<10$, which means that the musharaka profit sharing does not have multicollinearity symptoms. 
Astri Anantasari Azizah, Ade Yusuf Mujaddid, Dessy Noor Farida

Table 4. Multicollinearity Test

\begin{tabular}{ccc}
\hline & Tolerance & VIF \\
\hline Murabahah Margin Income & .222 & 4,513 \\
Istishna Margin Income ' & .713 & 1,403 \\
Mudharabah Revenue Sharing & .396 & 2,528 \\
Musyarakah Revenue Sharing & .438 & 2,877 \\
\hline
\end{tabular}

Dependent Variable: Net Income

\section{Heteroscedasticity Test}

The results obtained from the glacier test with a significant value on the independent variable are greater than 0.05 . This shows that there is no heteroscedasticity problem in this study.

It can be seen that the scatterplot graph shows that the dots spread randomly without forming a certain pattern. This means that there is no heteroscedasticity in this test regression model.

The results of the Autocorrelation test with a Durbin Watson value of 0.780 , in this test there are 24 samples with 4 independent variables. Then the table $\mathrm{dL}=1.0131$ and $\mathrm{dU}=1.7753$ is obtained, with the formula 4 - $\mathrm{dU}$ the result is 2.2247. The resulting Durbin Watson value is smaller than the $\mathrm{dL}$ value, thus obtaining a positive autocorrelation result. Positive autocorrelation is common in time series data because it is closely related to the dependence between data so that data for a certain period is tied to the previous data.

Table 5. Multiple Linear Regression Test Results

\begin{tabular}{cccccccc}
\hline & & \multicolumn{2}{c}{$\begin{array}{l}\text { Unstandardized } \\
\text { Coefficients }\end{array}$} & \multicolumn{2}{c}{$\begin{array}{c}\text { Standardized } \\
\text { Coefficients }\end{array}$} & \\
& Model & B & Std. Error & Beta & T & Sig. \\
\hline $\mathbf{1}$ & (Constant) & 13465,455 & 18585,542 & & .725 & .478 \\
& Murabahah Margin Income & .046 & .036 & .422 & 1,277 & .217 \\
& Istishna Margin Income ' & $-21,119$ & 10,255 & -380 & $-2,059$ & .053 \\
& Mudharabah Revenue Sharing & .603 & .288 & .518 & 2,093 & .050 \\
Musyarakah Revenue Sharing & -.018 & .064 & -.073 & -277 & .785 \\
\hline
\end{tabular}


The Effect of Margin Income and Shares of Financing ...

Table 6. Autocorrelation Test Results

\begin{tabular}{cccccc}
\hline Model & R & R Square & Adjusted R Square & Std. Error of the Estimate & Durbin-Watson \\
\hline $\mathbf{1}$ & $.735 a$ & .540 & .443 & 36336,530 & .780 \\
\hline
\end{tabular}

a. Predictors: (Constant), Musharaka Revenue Sharing, Istishna 'Margin Income, Mudharabah

Revenue Sharing, Murabahah Margin Income

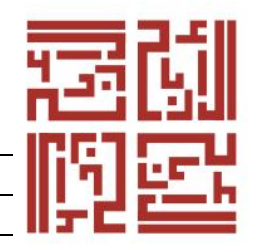

\section{Hypothesis Testing}

It shows that the value of Fcount is obtained 5,566 while the value of the Ftable distribution with an error rate of $\alpha=5 \%(0.05)$ is 3.10 which is obtained from table F, with the formula df (n1) = k-1 and df (n2) = n - k, where df (n1) degree of freedom as the numerator, $\mathrm{df}(\mathrm{n} 2)$ as the denominator, $\mathrm{k}$ (number of variables studied and $\mathrm{n}$ (amount of data). This shows that the value of Fcount 5,566> Ftable 3.10 and can be shown from a significant level of $0.04<0.05$ (5\% significant level). So it can be concluded that the variable murabahah margin income, istishna 'margin income, mudharabah profit sharing, and musyarakah profit sharing together have a positive and significant effect on the dependent variable, namely the net income variable.

The Effect of Murabahah Margin Income on Net Income. The value of Tcount is 1.277 with a significant value of 0.217 , which is greater than 0.05 . While the results of tcount $1.277<$ ttable 2.086 indicated.

Table 7. Simultaneous F Test Results

\begin{tabular}{|c|c|l|l|l|c|}
\hline Model & Sum of Squares & \multicolumn{1}{|c|}{ df } & Mean Square & F & Sig. \\
\hline Regression & $2.939 \mathrm{E}+10$ & 4 & 7348522181 & 5,566 & $.004 \mathrm{~b}$ \\
\hline Residual & $2.509 \mathrm{E}+10$ & 19 & 1320343380 & & \\
\hline Total & $5.448 \mathrm{E}+10$ & 23 & & & \\
\hline
\end{tabular}

a. Dependent Variable: Net Income

b. Predictors: (Constant), Musyarakah Revenue Sharing, Istishna 'Margin Income, Mudharabah Revenue Sharing, Murabahah Margin Income 
By the formula $\mathrm{df}=\mathrm{n}-\mathrm{k}(\mathrm{df}=24-4)$ and $\alpha=5 \%(0.05)$. So it can be concluded that the effect of the regression coefficient of Murabahah margin income on net income is negative and does not have a significant effect. The Effect of Istishna 'Margin Income on Net Income, The value of T count is -2.059 with a significant value of 0.053 which is greater than 0.05 . While the results of tcount $-2.059<$ ttable 2.086 are indicated by the formula $\mathrm{df}=\mathrm{n}-\mathrm{k}(\mathrm{df}=24-4)$ and $\alpha=5 \%(0.05)$. So it can be concluded that the effect of the istishna 'margin income regression coefficient on net income is negative and does not have a significant effect. Effect of Mudharabah Revenue Sharing on Net Income, the value of $T$ count is 2,093 with a significant value of 0.050 which is equal to 0.05 . While the results of tcount 2.093> ttable 2.086 are indicated by the formula $\mathrm{df}$ $=\mathrm{n}-\mathrm{k}(\mathrm{df}=24-4)$ and $\alpha=5 \%(0.05)$. So it can be concluded that the effect of the regression coefficient of mudharabah profit sharing on net income is positive and has a significant effect. The Influence of Musyarakah Revenue Sharing on Net Income, the value of $T$ count is -0.277 with a significant value of 0.785 which is greater than 0.05 . While the results of tcount $-0.277<$ ttable 2.086 are indicated by the formula $\mathrm{df}=\mathrm{n}-\mathrm{k}(\mathrm{df}=24-4)$ and $\alpha=5 \%(0.05)$. So it can be concluded that the effect of the regression coefficient of Musyarakah revenue sharing on net income is negative and does not have a significant effect.

\section{The Influence of Murabahah Margin Income on Net Profit at BRI Syariah Bank}

The results of the research from data processing state that the variable murabahah margin income has a significant effect on net income. This can be shown by the presence of the results from tcount $1.277<$ ttable 2.086, and a significance value of 0.217 , which means that the sig value is $0.217>0.05$. So it can be interpreted that the variable murabahah margin income has no significant effect on the net profit obtained by BRI Syariah, so that if the murabahah margin income increases, it will not affect the net profit generated at BRI Syariah.

Murabahais a buying and selling transaction with two parties between the seller and the buyer provided that the seller informs the buyer of the cost of the 
beaver or the object to be sold. So that buyers will know transparently what the cost of goods and profit margins will be given to sellers. In this murabahah contract, customers can also pay for goods or objects purchased in cash or installments.

The results of this study agree with the research conducted by Teri and Dian Novitasari „M.Pd (2020) with the title The Influence of Murabahah, Mudharabah, and Musyarakah Financing Income on Profitability in Islamic Banks listed on the Indonesia Stock Exchange, which shows that margin income murabahah has a negative and insignificant effect on net income.

Murabahah margin income variable does not significantly affect the net profit generated by BRI Syariah. It is assumed that in providing murabahah financing, the Bank does not selectively apply to prospective customers, resulting in congestion in financing repayments. The steps that should be taken are that the Bank must improve the principles for channeling financing to prospective customers so that refunds from customers to the Bank are carried out according to the agreed time, and the Bank will get the maximum profit or profit.

\section{The Influence of Istishna 'Margin Income on Net Profit at BRI Syariah Bank}

The results of the research from data processing state that the variable murabahah margin income has a positive effect on net income. This can be shown by the presence of the results from tcount $-2.059<$ ttable 2.086 , and a significance value of 0.053 , which means that the sig value is $0.053>0.05$. So it can be interpreted that the variable income margin istishna 'has no significant effect on the net profit obtained by Bank BRI Syariah. so that if istishna 'margin income increases, it will not affect the net profit generated at BRI Syariah.

An istishna 'transaction occurs when a company works or produces the goods ordered by the buyer. The goods that are the object of the order must have clear quality and specifications so that they do not experience errors at the time of work. Usually in the istishna 'contract the goods ordered are manufactured goods. This can be in the form of food / beverage products, household products, automotive products, or other manufactured products. 
Payment can be made at the beginning of the order or in installments, according to the agreement between the two parties.

The results of this study contradict the research conducted by Anggreany Hustia and Mister Candera (2019) entitled The Influence of Qardh, Ijarah, and Istishna Financing Revenues on Net Profits of Sharia People Financing Banks (BPRS) in Indonesia, which shows that Istishna Margin Income ' has a positive influence on net income.

The istishna 'margin income variable does not significantly affect the net profit generated by BRI Syariah. It is assumed that in providing financing with istishna' contract, the Bank does not selectively treat prospective customers, resulting in congestion in financing repayments. The steps that should be taken are that the Bank must improve the principles for channeling financing to prospective customers so that refunds from customers to the Bank are carried out according to the agreed time, and the Bank will get the maximum profit or profit.

\section{The Effect of Mudharabah Revenue Sharing on Net Profit at BRI Syariah Bank}

The results of the research from data processing stated that the Mudharabah profit sharing variable had a positive effect on net income. This can be shown by the presence of the results of Tcount 2.093> Ttable 2.086, so it can be interpreted that the profit sharing variable of mudharabah has a significant effect on the net profit obtained by BRI Syariah Bank.

Mudarabais a cooperation contract made between two or more parties, where the first party is the owner of the funds (shahibul maal), and the second party is the manager of the business (mudharib). Fund owners must provide all their funds (100\%) for the said business activity. If the business experiences a loss, then the loss will be borne by Shahibul Maal as the owner of the funds, as long as the business manager does not neglect. However, if in running a fund management business (mudharib) makes a negligence or error that results in losses during the business, the business manager is responsible for the loss. For the percentage of profits based on the profit sharing ratio agreed upon by the parties when making the initial agreement. 
The Effect of Margin Income and Shares of Financing ...

The results of this study agree with the research conducted by Juliana Putri and Intan Raudhatul Ma'wa (2017) with the title The Effect of Mudharabah Revenue Sharing and Musyarakah Profit Sharing on Sharia Bank Net Profits (Financial Statement Analysis of PT. Bank Syariah Mandiri, Tbk, Period 20132016), which shows that Mudharabah Revenue Sharing has a positive and significant effect on Net Income.

The profit sharing variable of mudharabah has a significant effect on the net profit generated by BRI Syariah. It is assumed that BRI Syariah has quite high income from the distribution of mudhabarah contract financing. As well as when the cooperation is carried out, there is minimal loss, so that the Bank does not incur large costs to overcome the losses that occur, therefore it can be said that the profit sharing revenue from mudharabah can affect the net profit generated by BRI Syariah.

\section{The Influence of Musyarakah Revenue Sharing on Net Profit at BRI Syariah}

The results of the research from data processing state that the revenue sharing variable of musyarakah has a positive effect on net income. This can be indicated by the presence of the results of tcount $-0.277<$ ttable 2.086 , and a significance value of 0.785 , which means that the sig value is $0.785>0.05$. So it can be interpreted that the revenue sharing variable musyarakah has no significant effect on the net profit obtained by Bank BRI Syariah.

Musharakais a cooperation agreement between two or more parties, in which all parties contribute to invest in a particular business. Profit and loss sharing will be shared in accordance with the agreement agreed by the parties.

The results of this study agree with the research conducted by Dimas Muhammad Fajar (2016) with the title The Effect of Mudharabah Revenue Sharing, Musyarakah Profit Sharing, and Murabahah Margin on the Profitability of Sharia Banks (Case Study at the Indonesian National Sharia Commercial Bank), which shows that income Musyarakah profit sharing has no significant effect on Net Income. 
The profit sharing variable of mudharabah has a significant effect on the net profit generated by BRI Syariah. It is assumed that BRI Syariah has not been able to overcome the risk of musyarakah financing, so it cannot increase profitability.

\section{The Influence of Murabahah Margin Income, Istishna 'Margin Income, Mudharabah Revenue Sharing, and Musyarakah Revenue Sharing on Net Profit at BRI Syariah}

The results of the research on the simultaneous hypothesis testing test notified in the F test state that the variables of Murabahah Margin Income, Istishna 'Margin Income, Mudharabah Revenue Sharing, and Musyarakah Sharing Income jointly affect the Net Profit at BRI Syariah. This is indicated by the number Fcount 5,566> Ftable 3.10 and can be shown from the significant level $0.04<0.05$ ( $5 \%$ significant level). So it can be concluded that Murabahah Margin Income, Istishna 'Margin Income, Mudharabah Revenue Sharing, and Musyarakah Sharing Income jointly affect BRI Syariah Net Profits.

\section{Conclusion}

Based on the results of research that has been carried out using multiple linear regression analysis regarding the effect of Margin Income and Profit Sharing on Net Profits obtained at BRI Syariah Bank, it can be concluded as follows: 1) The significant effect that resulted from the income margin of murabahah by using the $\mathrm{T}$ test got a result of 0.217 , which means that it is greater than 0.05 . This means that the murabahah margin does not have a significant effect on net income at BRI Syariah Bank; 2) The significant effect resulting from the income margin istishna 'by using the $\mathrm{T}$ test to get a result of 0.053 which means that it is greater than 0.05 . So it means that the istishna 'margin does not have a significant effect on net income at BRI Syariah Bank; 3) The significant effect generated from the profit sharing of mudharabah using the $T$ test results in 0.050 which means the same as 0.05 . So it means that mudharabah profit sharing has a significant effect on net income at BRI Syariah Bank; 4) The significant effect generated from the revenue sharing of musharaka using the $T$ test results in 0.785 , which means that it is greater than 
The Effect of Margin Income and Shares of Financing ...

0.05. it means that mudharabah profit sharing does not have a significant effect on net income at BRI Syariah Bank.

\section{References}

A. Wangsawidjaja. (2012). Pembiayaan Bank Syariah. PT.Gramedia Pustaka Utama.

Age, M. (2005). Teori Akuntansi. Almahera.

Andriyanto Et all. (2019). Manajeman Bank Syariah (Implementasi Teori dan Praktik). Qiara Media PartneR.

Ascarya. (2007). Akad dan Produk Bank Syariah. RajaGrafindo Persada.

Aufa, K., Dja'kum, C. S., \& E. (2019). Risks Of Sharia Commercial Bank In Indonesia: Analysis Of Internal And External Factors. Al-ARBAH : Journal Of Islamic Finance and Banking, 1(1).

Cahya Rosyadah, P., Rachmat Arifin, N., Muhtadi, R., \& Safik, M. (2020). Factors That Affect Savings In Islamic Banking. Journal of Islamic Finance and Banking, 2(1), 33-46. https://doi.org/10.21580/alarbah.2020.2.1.5499

Huda, N., \& Fajri, F. (2019). "The Analysis Of Musyarakah Contract Sharing System Implementationin BPRS Saka Dana Mulia Kudus". Jurnal AL. ARBAH: Journal of Islamic Finance and Banking, 1(1).

Lasmana, Y. (2009). Tanya Jawab Cara Mudah Mendapatkan Pembiayaan di Bank Syariah. PT.Alex Media Kompotind.

Mardani. (2015). Aspek Hukum lembaga Keuangan Syariah di Indonesia. Kencana.

Mashilal. (2020). . Risk Of Sharia Banking In Indonesia: Viewed From Types Of Financing. Jurnal Al-Arbah.

Muchtar, B. (2016). Bank dan Lembaga Keuangan Lain. Kencana.

Naja, H. R. D. (2011). , Akad Bank Syariah. Pustaka Yustisia.

Putri, J., \& Ma'wa., I. R. (2017). Pengaruh Pendapatan Bagi Hasil Mudharabah dan Bagi Hasil Musyarakah Terhadap Laba Bersih Bank Syariah. Jurnal JESkape, 2(2). 
Astri Anantasari Azizah, Ade Yusuf Mujaddid, Dessy Noor Farida

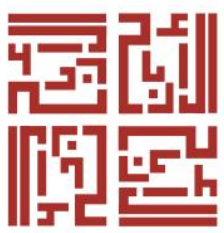

Sudarsono, H. (2003). Bank dan Lembaga Keuangan Syariah. UII Press. Usman, R. (2009). Produk dan Akad Perbankan Syariah di Indonesia. PT Citra Aditya Bakti.

AL-ARBAH | 82 